\title{
The financial instruments market - an institutional approach
}

\section{Zhanna Dovhan}

Doctor of Science, Banking Business Department, Ternopil National Economic University, Ukraine

\section{Igor Kravchuk}

\author{
Ph.D., Banking Business Department, Ternopil National Economic University, Ukraine
}

\section{Piotr Karaś}

\author{
Ph.D., Finance Department, Cracow University of Economics, Poland \\ (C) The Authors, 2017. This article is published with open access at ARMG Publishing.
}

\begin{abstract}
In response to the last financial crisis new institutional reforms were implemented. The aim for these reforms is to save and secure the functioning of markets in financial instruments. It seems though that these efforts lack the clarity of the basic notion, which is the term "institution". This weakness my cause interpretational problems on both theoretical and practical level. The aim of this article is to clarify the understanding of the notion of "institution" in finance. One of ways to achieve this goal is to present the institutional structure of the market in financial instruments, to specify the characteristics of both individual institutions and the whole environment in which they act. And, lastly, to outline an institutional transformation process which is driven by innovations. The classification of institutions is also proposed. As a result of analysis, following types of institutions are singled out: institutions in a broad meaning (established through institutional contracts), institutions in a narrow sense (norms and social rules). Additionally, the formal and informal institutions are distinguished.
\end{abstract}

Keywords: financial instruments market, institution, transformation bridge, bounded rationality, opportunism.

JEL Classification: G18, G20, O16.

\section{Introduction}

The modern financial instruments market constitutes one of the indispensable elements of contemporary economies. The mechanisms of the market offer numerous capabilities for the transformation of funds and the aim of its operation is their efficient allocation. Experience shows that this aim is not always fulfilled, especially at times of crisis. Disruptions of the financial markets may be a source of system risk which can translate not only into the remaining areas of the financial system but also the actual sphere of economies.

In response to the latest global financial crisis the implementation of reforms, including the institutional ones, has been started with the aim of ensuring the stability of the operation of the financial instruments market. It seems that the ambiguous understanding of the concept of the "institution" is one of the weaknesses of this process. This is noticeable both on the theoretical plane, as well as in practice. That is why developing a straightforward and coherent approach to the financial instruments market within the institutional paradigm of economic theory is such an important task in the research of financial area.

\section{Literature review}

Issues concerning the nature of the institution, the institutional approach to economics and the financial system has been the subject of research by a broad circle of researchers. Among them the following should be especially noted by R. Coase, J. Stiglitz, J. Commons, G. Hodgson, D. North, O. Williamson, J. De Sousa, J. Jütting, J. Solarz. Despite this widespread interest from researchers, the institutional aspect of the operation of financial markets appears to be insufficiently developed and demands additional research.

The aim of this article is to prove a clarification of understanding of the nature of the institution in the area of finance, including: the presentation of the institutional structure of the financial instruments market, extracting characteristic traits both for individual institutions and the environment in which they operate, as well as 
outlining the process of institutional transformation in the innovation-driven sector of negotiable financial instruments.

\section{The main findings of the study}

The term "institutionalism"has been related to economics from the start. It was first used in a private conversation by Robert Hoxie who defined himself as an institutional economist. First the term was used in public by Walton Hamilton who in 1918 delivered a paper titled "The Institutional Approach to Economic Theory"(Pieliński, 2014) at the convention of the American Economic Association.

Classical institutionalism, which developed at the turn of the 19th and 20th century, can be divided into two trends: 1) the social-psychological one which understands institutions as the dominant ways of thinking and the resulting rules of behavior in the relations between an individual and a community (Veblen, 1899); 2) the legal one where institutions are, above all, legal norms regulating economic life (legal control of commodities and labor) (Commons, 1931).

On the basis of views expressed by J.R. Commons and in neo-classical works in the 1930s a new institutional economics (NIE) was born. It describes institutions as principles (rules) of a social game or as standards of social behavior. In particular, the concept of "institution" also refers here to enterprises. As J.K. Solarz notes, institutions are bridges, social phenomena on the meso-level which connect and bind together the basic, external levels of activity: micro and macro, that is the level of individual activities with the level of the operation of the social system (Solarz, 2012).

The most commonly accepted definition of institution was formulated by D. North. According to him "institutions are the rules of the game in society or, more formally, are the humanly devised constraints that shape human interaction. In consequence, they structure incentives in human exchange, whether political, social or economic" (North, 1993). On the other hand, A. Schotter (1981) perceives institutions not as rules of a game, but as standards (regularities) of behavior, which emerge while problems in recurrent social games are solved (recurrent game, "supergame"). Due to the recurrent character of games, in their process of learning, subjects (agents) develop behaviors which they recreate in successive games (regularities in behavior). Those which transform into standard behaviors are called institutions.

New institutional economics conducts research in two areas: (1) the institutional environment: property rights theory (H. Demsetz and A. Alchian), public choice theory (J. Buchanan, D. Tallock), and new economic history (D. North); (2) institutional contracts: agency theory (M. Jensen, W. Merkling, J. Stiglitz), and transaction cost theory (R. Coase, O. Williamson). The institutional environment comprises rules, norms, and constraints which create the framework of activity of individuals, organizations and the society. Institutional contracts are agreements between particular entities to reduce information asymmetry and transaction costs.

For example, G. Hodgson refers to the concept of "institution", stating that the market is in itself an institution. The market is, after all, a set of social norms and customs, instituted exchange relations and the exchange of information (information networks) (Hodgson, 2004). Moreover, he believes that one important type of institution is a capitalist company, the function of which is not only to minimize costs but also to shape the kind of institutional scheme which partly changes their calculation. On the other hand, O. Williamson (1998) draws attention to the fact that such economic institutions as companies, markets and long-term relations between parties are a product of an astounding series of organizational innovations.

In an attempt at systemizing the multitude of approaches one can offer an understanding of the institution in both a narrow and in a broad sense. From the first perspective, institutions shape the environment (the socalled institutional environment), in other words they are a sum total of norms, customs, constraints and rules (for example legal acts, good business practices), which allow the organization of the efficient functioning of the society, including its economy. In the broad sense, institutions are not only norms and rules, but also companies, markets and other organized structures founded on their basis.

One can explain the forming of institutional entities on the financial instruments market by applying R. Coase's approach. Transaction costs which individual investors would have to bear to enter into and maintain some relations with other entities on the market (e.g., collecting indispensable information, conducting the analysis of investment attractiveness of assets, or purchasing financial instruments directly from issuers) may be larger than the founding and operation costs of institutions operating as intermediaries in negotiable financial instruments. The cost ratio can, then, be a factor determining the organization of the operation of the 
financial market in the institutional form. The author of the theory of transaction costs writes, "...the operation of a market costs something and by forming an organization and allowing some authority (an "entrepreneur") to direct the resources, certain marketing costs are saved" (Coase, 2013). The entrepreneur has a choice: to either function within the framework of the institution he or she set up, which is the enterprise, or to operate on the market individually. The choice of the way of functioning is determined by the transaction costs related to each of the variants of the activity. In other words, "(...) the reason for the introduction of the firm is due primarily to the existence of marketing costs" (Coase, 2013).

The institutional structure of the financial instruments sector can be considered from the perspective of the three-level analysis suggested by O. Williamson (1995): the level of the institutional environment, contracts and individual investors (Figure 1). The result of finalizing institutional contracts are markets and market participants.

Institutional contracts in the financial sector are a bond binding together all the elements. By their virtue entities which are important participants in the trading of financial instruments are created. These include institutions which: fulfill the role of markets (stock exchanges, multilateral trading facilities, organized trading facilities); acquire funds (issuers); allocate both their own and their clients' available financial resources (institutional investors); provide services facilitating or allowing the completion of transactions on financial markets (brokerage houses); and/or, finally, perform the function of operational support for the completion of transactions (depository and clearing companies).

In a given institutional environment an individual investor (surplus entity) may, then, be able to complete financial investments by making a contract directly with the deficit entity, i.e., one searching for funding. Such an investor may also use the institutional opportunities of the existing financial system, i.e., the financial markets and intermediaries, and may also create his or her own institution which will engage in trading in financial instruments. In accordance with NIE's stand, the choice of the best option is determined by, among others, transaction costs.

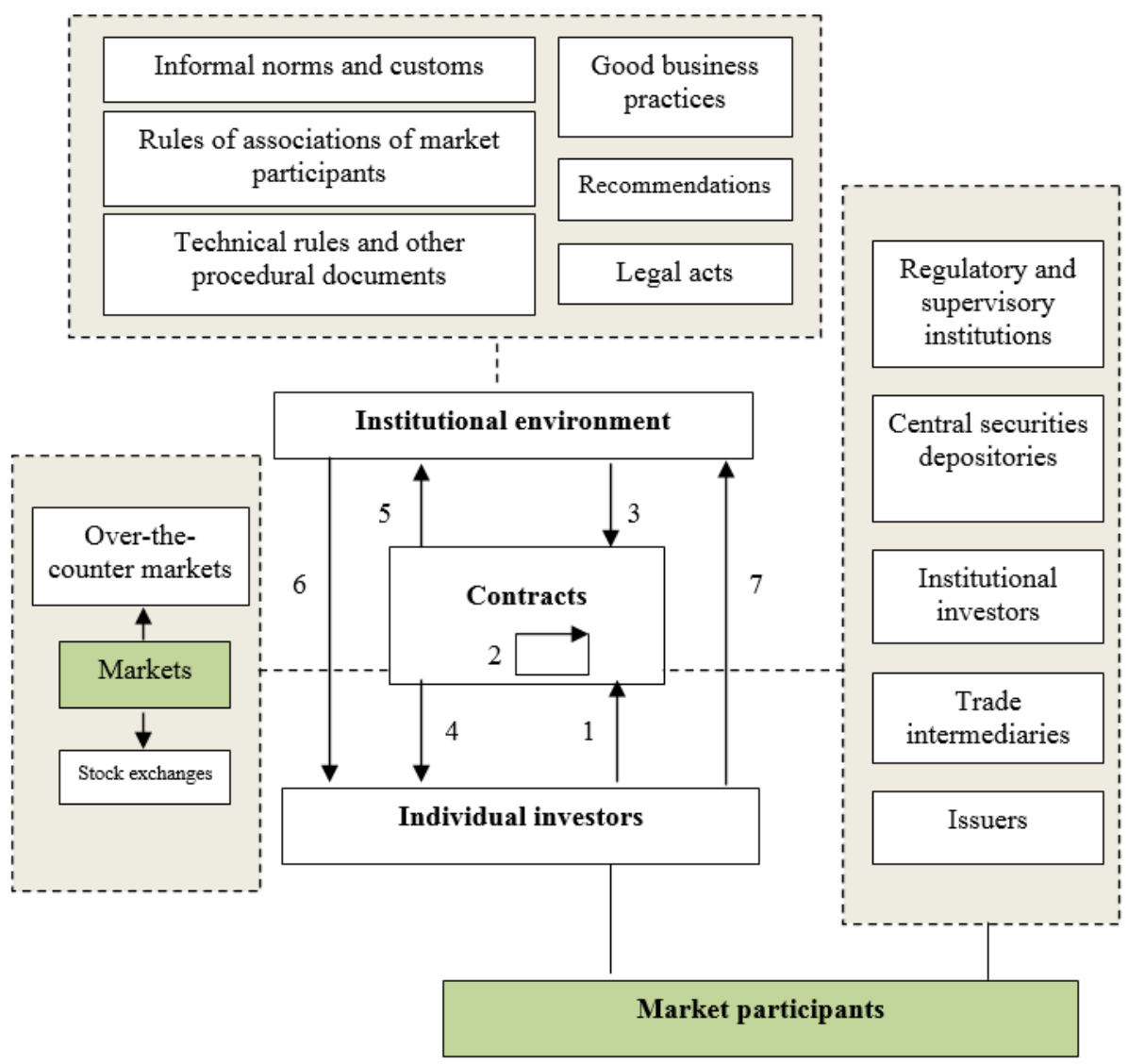

Figure 1. The institutional structure of the financial instruments sector 
The characteristic traits of the contemporary stage of the institutional development of the financial markets are: (1) trans-border and trans-sector expansion, which are motivated by a willingness to use the so-called synergy effect. For example, lowering transaction costs may be carried out via the intra-company reconciliation of liquidity shortages and surpluses of individual entities, and not via the use of the intermediation of the financial markets (in particular the monetary market); (2) outsourcing, that is transferring specific sorts of operations onto a third party (for example, the purchase of analytical information generated by firms in India by large banking institutions in the USA, because the former produce analytical products at less expense than American banks could do so themselves).

New institutional economics indicates the following characteristic traits for both institutions in the broad sense, as well as retail investors:

1. bounded rationality - understood as a limited ability to set correct goals and as making sub-optimal choices from among available options. The concept of bounded rationality was described by Nobel Prize Winner H. Simon (1961). Contemporarily, in the theory of economics this way of perceiving entities is being developed by the behavioral finance trend, which refers bounded rationality to the behavior of the participants in financial markets. In practice, in order to make decisions in conditions of uncertainty, investors do not use the probability theory apparatus or mathematical statistics, as postulated by the canonical version of the rational expectations theory, but they employ heuristics, which refer to human experience and intuition. In other words, people are not homo-economicus in the traditional understanding of the word, i.e., actors which behave in accordance with axioms of rationality and whose decisions are influenced by facts only. Irrational behaviors of investors in the markets are described within D. Kahneman and A. Tversky's prospect theory (Kahneman and Tversky, 1979). For instance, it is shown that investors have a tendency to maintain a loss-generating position, as they count on a reversal of the trend. Nobel Prize Winner R. Shiller indicates the principal difference between technical and institutional innovations. It is, namely, the influence of the human factor. The process of creating and implementing innovation in the sphere of economic institutions encounters numerous problems and impediments whose source is human imperfection. In this context Shiller believes that behavioral economics has an essential meaning for institutional innovations, as it allows one to comprehend and limit the influence of the human factor (Shiller, 2005);

2. methodological individualism and opportunism - in accordance with the former the operation of the institution in the broad sense is explained from the perspective of the activities of individual entities ${ }^{1}$. On the other hand, 'opportunism' can be understood as "self-interest seeking with guile (...) [This term refers] to the incomplete or distorted disclosure of information, especially to calculated efforts to mislead, distort, disguise, obfuscate, or otherwise confuse" (Coase, 2013). Popular manifestations of opportunism on the financial instruments market include the manipulation of information, the manipulation of price and socalled insider trading, the source of all which can be traced back to information asymmetry and the resultant moral hazard;

3. exogeneity and permanence of preference, which manifests itself in the application of permanent criteria in the selection of financial assets by retail investors. The system of preference is exogenic as regards relations between individuals, so it is shaped beyond the model of their interaction.

Contemporarily, three attributes can be assigned to operating institutional environment of the financial markets:

1. asymmetry of information - is one of the main problems in achieving efficiency of financial instruments markets. Understood in its classical sense - after E. Fama (1970) - so-called strong-form efficiency of the market assumes full and simultaneous access to all information for each market participant. This approach can be treated in a postulative manner, that is not as factual circumstances, but the desired destination. One may perceive, for example, the introduction of the Electronic Data Transfer System (EDTS) and the Electronic Information Base (EIB) in Poland as an attempt at, and example of, striving to reduce the asymmetry of information. Within these systems issuers of securities are obliged to reveal any and all information which may have an essential significance from the point of view of their economic situation,

\footnotetext{
${ }^{1}$ This approach, however, is criticized, e.g. G. Hodgson (2007) believes that the concept of "methodological individualism" should be completely rejected.
} 
economic position and/or financial standing, or which could affect the rating of the financial instruments they have issued;

2. non-homogeneity (heterogeneity) of financial products - results from the diversification of the financial potential of issuers of securities. In consequence, the issuing and trading of financial instruments may happen in different segments of the market (for example, in Poland the following are in operation: Warsaw Stock Exchange, BondSpot, Catalyst, NewConnect, and OTC market);

3. imprecise specification of property rights - is applicable in particular to developing countries in which legal norms may lead to the rise of ownership conflicts (this phenomenon is widespread in Ukraine).

For the effective and transparent operation of the negotiable financial instruments market it is essential for both the state and other institutions to create the proper institutional environment. This kind of environment is shaped by relevant rules, norms, sanctions, and recommendations. Such narrowly understood institutions can be divided into formal and informal ones. Those created and propagated via official channels, i.e. by regulatory institutions in the broad sense (in Poland, among others, by the Polish Financial Supervision Authority) can be counted among the first group. The most important formal institutions are legal norms concerning the regulation and supervision of the trading of financial instruments, including sanctions for the misuse of funds which can lead to disruptions on the financial market. On the other hand, informal institutions are socially sanctioned norms of conduct and customary developments, modifications of formal rules. Informal institutions arise automatically (self-enforcement mechanism), i.e. without the sanctions of formal norms. These institutions have their legal basis in, amongst others, an internalized sense of duty, the expectation of reciprocity, and the conviction that adherence to the norms will be beneficial for both sides, but also in, for example, the threat of force (Jütting and De Sousa, 2007). Informal institutions can, then, exert a positive (e.g. the execution of the provisions incorporated in Good Practices of Warsaw Stock Exchange listed companies) or negative influence on the relations between market participants. In particular corruption practices which can be observed in, for example, some countries of the former Soviet Union or Latin America are informal institutions. A case in point being situations of inadequate protection of investors, i.e. where owning stocks does not guarantee that competition will not take over a given business entity with the use of corruption practices by means of civil law proceedings. Between 2008-2009 in Ukraine issuers of corporate bonds conducted bankruptcy procedures not to regulate their obligations, and transferred their liquid assets to other companies they set up. The largest scale of institutionalized corruption practices was linked to privatization in countries of the former Soviet Union. For example, in Ukraine some of the existing stock exchange markets were used solely for the corrupting sale of state property. Corruption mechanisms are used on the capital market also within the misconduct of so-called money laundering, or covering up the actual beneficiaries of financial transactions.

According to the Transparency International Report (2014) even among countries of the European Union the levels of corruption vary widely. The lowest scale of corruption is characterized by Denmark, and the highest by Romania, Italy, Greece and Bulgaria. Interestingly, Cuba and Ghana have less corruption than some member states of the EU. In 58\% of the countries belonging to the G20 group the Corruption Perceptions Index amounts to less than 50 (where 100 means the highest transparency, and 0 the highest corruption).

Creating institutions in the broad sense, in particular ones which are responsible for regulation and supervision, is to serve the kind of formation of an institutional environment which will let it fulfill its functions in an efficient way, that is, to provide:

1. framework regulation, that is the kind of financial laws which guarantee the transparent and non-discriminatory mechanism of monetary resources allocation by means of financial instruments; within this regulation a catalogue of the kinds of licensed activities also should be found;

2. predictability and stability of the negotiable financial products system thanks to the introduction of the institution of eliminating information asymmetry;

3. freedom and safety-the financial instruments market is to ensure its participants the right to the free choice of the means and size of the institution depending on risk tolerance, while at the same time ensuring an adequate system of protection of investors' property rights;

4. minimization of transaction costs, in particular the costs of acquiring new clients and of the operational risk of completing transactions; 
5. the exchange of knowledge, thanks to which it is possible to increase investors'involvement in the negotiable financial instruments market. Such exchange may be completed by means of two groups of institutions, i.e., formal ones and informal ones understood in the narrow sense.

An important aspect of institutional development of the negotiablefinancial instruments sector is innovativeness and efficient transformation of the institution performed by means of appropriate bridges (fig. 2). The transformation bridge is a set of institutional stimuli which contribute to the creation of the institution and stimulate its evolution. Stimuli consist in the already existing, individual kinds of institutions, especially the legal norms of the growth of appeal of innovative investments (for example tax relief), institutions organized as business incubators, technology parks, think tanks, and others.

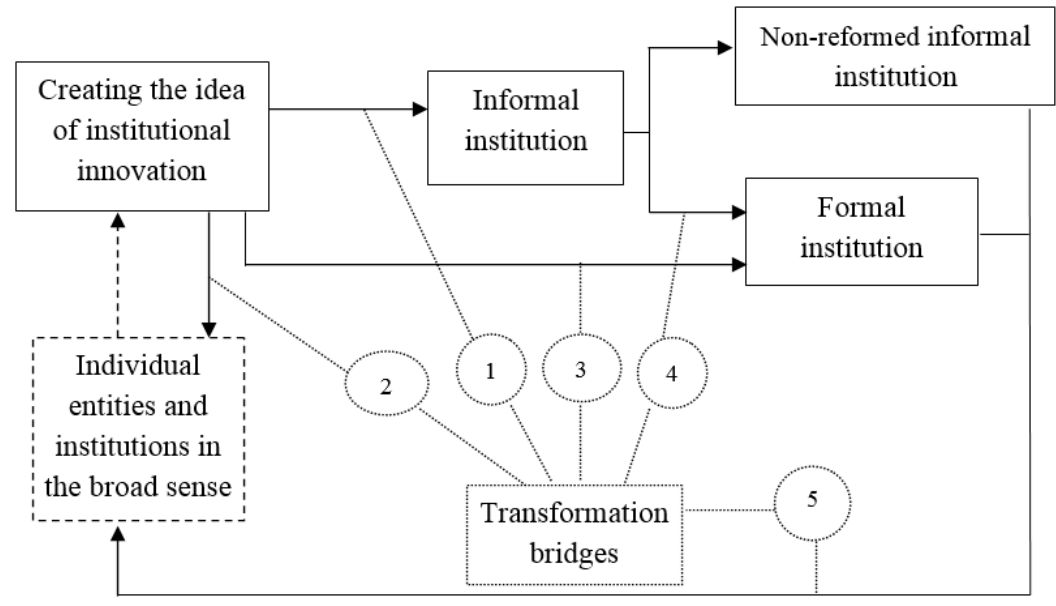

Figure 2. The process of institutional transformation

Source: Own elaboration.

With the help of the first transformation bridge a financial innovation changes into an informal institution in the strict sense. This innovation is initially used exclusively by its creator, but with time, when its merits are confirmed, its diffusion as an informal institution takes place. Within the second transformation bridge innovation materializes directly in the form or modification which already exists, or by establishing a new institution in the broad sense. Such a transformation is possible only if there is no need to create new formal institutions in the narrow sense.

Within the third transformation bridge it is possible to translate innovation directly into legal norms (formal institutions). However, this path conceals a danger that the innovation which has been implemented without prior verification in practice may in future turn out to be inefficient or erratic. Narrowly understood institutions of informal character may transform into formal institutions via the fourth transformation bridge. For example, a risk management model utilizing the Value at Risk method was introduced by the JP Morgan Bank as a Risk Metrics service, then to enter the Basel II regulation (Holton, 2002). There exist, however, such informal institutions which cannot transform into norms or formal rules, and this is why they remain non-reformed informal institutions. Among them are, for example, specific rules of behavior in conducting the investment (e.g., connected with the investors' self-discipline, such as individual setting of the automatic completion of stop-loss or take-profit defense transactions), and national customs of conducting negotiations between partners. Via the fifth transformation bridge new formal institutions affect the change of the existing ones or the creation of new institutions in the broad sense. One can understand the creation of the KDPW_CCP S.A. Company in 2011 as a subsidiary entity to the Polish National Depository for Securities as such a transformation.

The other important dimension of transformation - besides the creation of new institutions -is limiting or eliminating institutions which have a deficient influence on the development of the sector as a whole. It is an exceptionally difficult task, especially in reference to the generally accepted informal institutions. In Ukraine, for example, an informal institution in the form of a generally held conviction that speculation on the market is a crime exists. In the market economy, though, speculation is perceived as one of the ways of lawful shortterm investment activity. It seems that knowledge exchange (development of financial culture) as a function of the institutional environment may contribute to changing such attitudes. 


\section{Conclusions}

The conducted attempt at applying the institutional approach to the financial instruments market allows one to define the structure of the sector, the specificity of interactions between particular elements and the directions of influence (transformation bridges) which may be exerted by different institutions on innovative development and growth of efficiency of this sector.

Based on the analysis of different outlooks on the essence of the institution it has been proposed to identify institutions in the broad sense, i.e. such that develop as a result of institutional contracts and institutions in the narrow sense (norms and rules) which are the elements of the institutional environment.

The analysis of basic traits of specific entities and the institutional environment is a proof of the need to undertake activities limiting weaknesses in the sector such as opportunism, bounded rationality, asymmetry of information, and imprecise specification of property rights.

The development of the financial market is possible when both the institutions of this market and individual investors perform a comparative analysis of the effectiveness of the use of individual innovation, transformation bridges, and institutions.

\section{References}

1. Coase, R.(2013). Firma, rynek i prawo. Warszawa. Oficyna a Wolters Kluwer business.

2. Commons, J.R. (1931). Institutional Economics.The American Economic Review, 21(4), 648-657.

3. Fama, E.F. (1970). Efficient Capital Markets: A Review of Theory and Empirical Work. The Journal of Finance, 25(2), 383-417.

4. Hodgson, G. (2007). Meanings of Methodological Individualism. Journal of Economic Methodology, $14(2), 211-226$.

5. Hodgson, G. (2004). The Evolution of Institutional Economics. London, New York,Routledge.

6. Holton, G.A. (2002).History of Value-at-Risk: 1922-1998. Working Paper, Boston, Massachusetts.

7. Jütting, J. De Sousa I. (2007). Informal institutions and development: How they matter and what makes them change. In Informal Institutions: How Social Norms Help or Hinder Development. OECD Publishing, pp. 29-43.

8. Kahneman, D., Tversky A. (1979). Prospect Theory: An Analysis of Decision under Risk. Econometrica, 47(2), 263-291.

9. North, D.C.(1993). Institutions, institutional change and economic performance. Cambridge, New York, Oakleigh, Cambridge University Press.

10. Pieliński, B. (2014). Instytucjonalizmy w analizach polityki społecznej. Retrieved from http://rszarf.ips.uw.edu.pl/pdf/obce/instytucjonalizmy.pdf. Accessed December 12, 2016.

11. Schotter, A. (1981). The Economic Theory of Social Institutions.Cambridge, Cambridge University Press.

12. Shiller, R. (2005). Behavioral Economics and Institutional Innovation. Southern Economic Journal, 72(2), 268-283.

13. Simon, H. (1961). Administrative Behavior.New York,McMillan.

14. Solarz, J.K. (2012). Nanofinanse. Codzienność zmienia świat. Warszawa, Wydawnictwo C.H. Beck.

15. Transparency International, Corruption Perceptions Index (2014). Retrieved from http://www.transparency.org/cpi2014/in_detail. Accessed 10 December 2016.

16. Veblen, T. (1899). The Theory of the Leisure Class.New York, Macmillan.

17. Williamson, O. (1998). Ekonomiczne instytucje kapitalizmu: firmy, rynki, relacje kontraktowe. Warszawa, Wydaw. Naukowe PWN.

18. Williamson, O. (1995). Hierarchies, markets and Power in the Economy: An Economic Perspective. Industrial and Corporate Change, 4(1), 21-49. 